\title{
Dependence of Intrapulmonary Pressure Amplitudes on Respiratory Mechanics during High-Frequency Oscillatory Ventilation in Preterm Lambs
}

\author{
J. JANE PILLOW, PETER D. SLY, ZOLTAN HANTOS, AND JASON H.T. BATES \\ Clinical Sciences Division, Centre for Child Health Research, Subiaco, West Perth, Western Australia \\ [J.J.P., P.D.S., Z.H.]; Princess Margaret and King Edward Memorial Hospitals, Subiaco, Western \\ Australia [J.J.P., P.D.S.]; Department of Medical Informatics and Engineering, University of Szeged, \\ Szeged, Hungary [Z.H.]; Departments of Medicine and Molecular Physiology and Biophysics, University \\ of Vermont, Burlington, Vermont, U.S.A. [J.H.T.B.]
}

\begin{tabular}{|c|c|}
\hline \multicolumn{2}{|c|}{ ABSTRACT } \\
\hline $\begin{array}{l}\text { In the healthy animal lung, high-frequency oscillatory ventilation } \\
\text { (HFOV) achieves effective ventilation at tidal volumes }\left(\mathrm{V}_{\mathrm{T}}\right) \text { less } \\
\text { than or equal to dead space while generating very small pressure } \\
\text { fluctuations in the alveolar spaces }\left(\Delta \mathrm{P}_{\mathrm{A}}\right) \text {. We hypothesized that the } \\
\text { respiratory mechanical parameters influence the magnitude of the } \\
\text { intrapulmonary pressure fluctuations during HFOV. A computer } \\
\text { model of the neonatal respiratory system was used to examine the } \\
\text { independent effects of altering the compliance, nonlinear and linear } \\
\text { resistance, and inertance of the respiratory system on } \mathrm{V}_{\mathrm{T}} \text {, and cyclic } \\
\text { intrapulmonary pressures under homogeneous and heterogeneous } \\
\text { conditions. The impact of low compliance on the transmission of } \\
\text { pressure from the airway opening to the trachea }\left(\Delta \mathrm{P}_{\mathrm{tr}} / \Delta \mathrm{P}_{\mathrm{a}} \text { ) and }\right. \\
\left.\text { alveolar compartment ( } \Delta \mathrm{P}_{\mathrm{A}} / \Delta \mathrm{P}_{\text {ao }}\right) \text { during HFOV was determined in } \\
\text { a preterm lamb lung model. In the computer model, an increase in } \\
\text { flow-dependent resistance to simulate changing the internal diame- } \\
\text { ter of the tracheal tube from } 4.0 \text { mm to } 2.5 \text { mm halved the trans- } \\
\text { mission of the pressure waveform to both the carina and the alveolar } \\
\text { compartment. Increased peripheral resistance was associated with } \\
\text { an increased } \Delta \mathrm{P}_{\mathrm{tr}} / \Delta \mathrm{P}_{\text {ao }} \text { but a reduction in } \Delta \mathrm{P}_{\mathrm{A}} / \Delta \mathrm{P}_{\text {ao }} \text {. The } \Delta \mathrm{P}_{\mathrm{A}} / \Delta \mathrm{P}_{\mathrm{ao}} \\
\text { also decreased with increasing alveolar compartment compliance, a } \\
\text { finding that was verified in the preterm lamb lung. There was an } \\
\text { exponential decrease in the magnitude of } \Delta \mathrm{P}_{\mathrm{A} 1} \text { compared with } \\
\Delta \mathrm{P}_{\mathrm{A} 2} \text { as the ratio of the time constants of the two parallel compart- } \\
\text { ments }\left(\tau_{1} / \tau_{2}\right) \text { increased in the heterogeneous computer lung model. } \\
\text { The transmission of driving pressure amplitude to both the proximal } \\
\text { airways and lung tissue during HFOV is dependent on lung me- } \\
\text { chanics and may be greater in the poorly compliant lung than that }\end{array}$ & 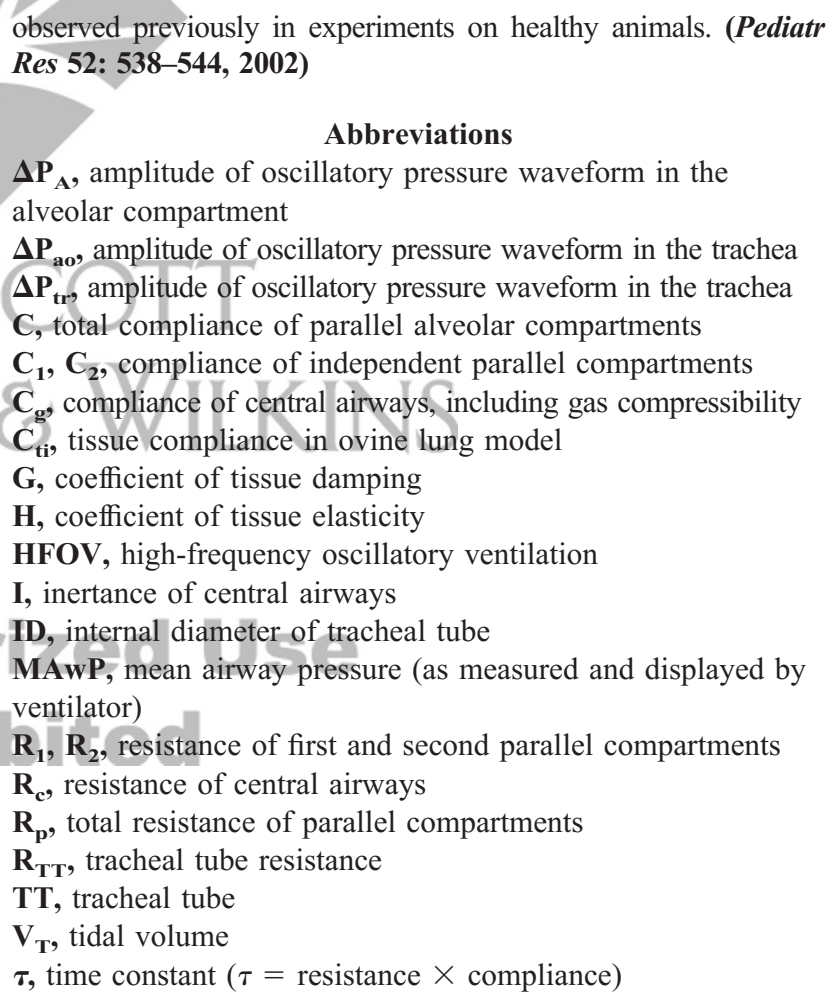 \\
\hline
\end{tabular}

One of the purported advantages of HFOV is the achievement of adequate gas exchange at low intrapulmonary pressure

Received December 31, 2001; accepted March 26, 2002.

Correspondence: Jane Pillow, Portex Unit, Institute of Child Health, 30 Guilford St, London WC1N 1EH, U.K.; e-mail: j.pillow@ich.ucl.ac.uk

A SensorMedics 3100A high-frequency oscillator was the loan of SensorMedics Corporation, (Yorba Linda, CA, U.S.A.). A Florian Monitor and hot-wire anemometer was the loan of Anaequip, Melbourne, Australia. J.J.P. was the recipient of a National Health and Medical Research Council (Australia) Medical Postgraduate Scholarship during the period these studies were undertaken.

DOI: 10.1203/01.PDR.0000030875.20888.64 amplitudes and $\mathrm{V}_{\mathrm{T}}$. At least in theory, HFOV should reduce the potential barotrauma and volutrauma that are commonly associated with more conventional ventilatory modalities and which may be vitally important in the structurally and functionally immature preterm lung. The experimental evidence supporting the generation of small $\Delta \mathrm{P}_{\mathrm{A}}$ during $\mathrm{HFOV}$ was obtained in healthy adult rabbits (1) and excised adult dog lungs (2). Only one study has obtained direct measurements of $\Delta \mathrm{P}_{\mathrm{A}}$ in both a normal and abnormal lung model (3). Although 
the primary focus of that study was to determine whether ventilation settings could be optimized during HFOV, Kamitsuka et al. (3) made an incidental observation that higher alveolar pressure amplitudes were observed during HFOV in rabbits after saline lung lavage than in the nonlavage group. Further evidence to support their observations has come from recent theoretical (4) and in vitro (5) studies that have shown lung compliance to be a major factor determining pressure transmission to both the lung model compartment (5) and to the end of the TT (4). No theoretical or in vivo studies, however, have systematically explored the effect that respiratory disease may have on the transmission of pressure amplitude to both the trachea and parenchyma during effective ventilation with HFOV.

Although HFOV has shown clear short-term advantages in the achievement of more efficient ventilation and rapid weaning of fraction of inspired oxygen $\left(\mathrm{FiO}_{2}\right)(6-9)$, efficacy in reducing the incidence of chronic lung disease has only proved to be statistically significant when meta-analysis is confined to trials employing both early study recruitment $(<12 \mathrm{~h}$ age $)$ and an open lung volume strategy (10). Changes in lung volume will influence the mechanical behavior of the respiratory system and have been shown to have consequences for transmission of both pressure and volume in the excised lungs of healthy rabbits during oscillation with HFOV (11). We asked, therefore, how the different mechanical parameters of the intubated respiratory system might influence the magnitude of the cyclic distending pressures within the preterm lung.

\section{MATERIALS AND METHODS}

Study design. A computer model was used to systematically evaluate the effect of changes in the/mechanical properties of the intubated respiratory system on both $\mathrm{V}_{\mathrm{T}}$ and the cyclic fluctuations in the intrapulmonary pressure waveforms during HFOV. The impact of low lung compliance on the transmission of pressure amplitude to the trachea and the alveolar compartment was studied in the surfactant-deficient, structurally immature preterm ovine lung.

Computer simulations and analysis. The computer model is a simple lumped system driven by an oscillatory pressure waveform applied to the airway opening (Fig. 1). The system includes two parallel alveolar compartments having a compli-

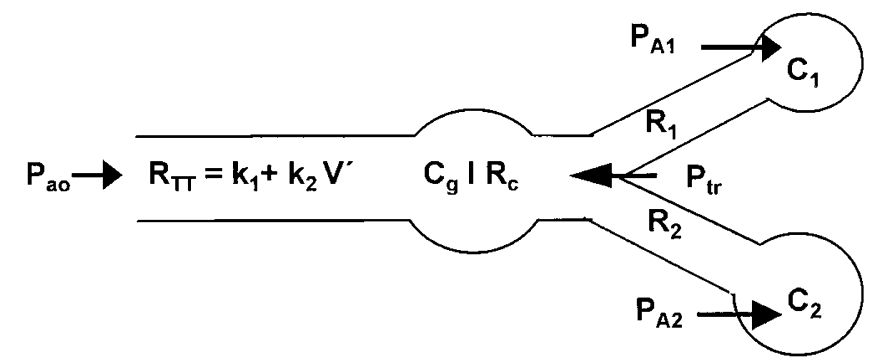

Figure 1. Parallel compartment computer model. An oscillatory pressure waveform $\left(\mathrm{P}_{\mathrm{ao}}\right)$ was applied to the airway opening. The effects of varying each of the individual model components were studied while other parameters were held constant. $\left(\mathrm{R}_{\mathrm{TT}}\right)$ TT resistance; $\left(\mathrm{k}_{1}, \mathrm{k}_{2}\right)$ Rohrer constants; $\left(\mathrm{P}_{\mathrm{A}}\right)$ alveolar pressure; $\left(\mathrm{P}_{\mathrm{tr}}\right)$ pressure at the junction of the parallel compartments; (I) central airways inertance, $\left(\mathrm{C}_{\mathrm{g}}\right)$ central compliance; $\left(\mathrm{R}_{\mathrm{c}}\right)$ central airways resistance; $\left(\mathrm{R}_{1}, \mathrm{R}_{2}\right)$ peripheral resistances; $\left(\mathrm{C}_{1}, \mathrm{C}_{2}\right)$ alveolar compartment compliance. ance $\left(\mathrm{C}_{1}\right.$ or $\left.\mathrm{C}_{2}\right)$, each associated with a peripheral resistance $\left(\mathrm{R}_{1}\right.$ or $\mathrm{R}_{2}$, respectively). A central airway with mechanical properties that incorporate an inertance $(\mathrm{I})$, compliance $\left(\mathrm{C}_{\mathrm{g}}\right)$, and a resistance $\left(R_{c}\right)$ connects $R_{1}$ and $R_{2}$ to the tracheal opening. A flow-dependent resistance was included between the central airway compartment and the airway opening to account for the resistive effects of turbulent flow through the $\mathrm{TT}$, such that $\mathrm{R}_{\mathrm{TT}}=\mathrm{k}_{1}+\mathrm{k}_{2}\left|\mathrm{~V}^{\prime}\right|$ where $\left|\mathrm{V}^{\prime}\right|$ is the absolute flow. The equations solved by the model at each time step are identical to those described by Bates et al. (12), with the exception that the flow-dependent resistance is substituted for the linear resistance between the airway opening and the proximal compliance.

The oscillatory driving pressure $\left(\mathrm{P}_{\mathrm{ao}}\right)$ used in the simulations was recorded at the airway opening of an in vitro lung model similar to that described by Fredberg et al. (13), using a gauge pressure transducer (TG-40, SCIREQ Scientific Respiratory Equipment Inc., Montreal, Quebec, Canada), which has a flat frequency response to $1 \mathrm{kHz}$, and a SensorMedics $3100 \mathrm{~A}$ high-frequency oscillator (SensorMedics Corporation, Yorba Linda, CA, U.S.A.) set to deliver HFOV at $15 \mathrm{~Hz}, 33 \%$ inspiratory time, and a ventilator-displayed amplitude $\left(\Delta \mathrm{P}_{\text {vent }}\right)$ of $40 \mathrm{~cm} \mathrm{H}_{2} \mathrm{O}$. The waveform was sampled at $2 \mathrm{kHz}$ and filtered at $500 \mathrm{~Hz}$ (LABDAT, RHT-InfoDat, Inc., Montreal, Quebec, Canada). A set of baseline conditions was established for the mechanical properties of the intubated neonatal respiratory system, as defined in Table 1 . Values for the constants $\mathrm{k}_{1}$ and $\mathrm{k}_{2}$ for the nonlinear resistance of TT of varying ID and cut lengths during both inspiration and expiration were assigned using the data published by Sly et al. (14). The compliance of the central airways and proximal compartment $\left(\mathrm{C}_{\mathrm{g}}\right)$ was assigned as $0.01 \mathrm{~mL} / \mathrm{cm} \mathrm{H}_{2} \mathrm{O}$, representing a gas volume of approximately $10 \mathrm{~mL}$ for equipment and physiologic dead space (13). Values for I, and the total compliance of the parallel compartments $\left(\mathrm{C}=\mathrm{C}_{1}+\mathrm{C}_{2}\right)$ were $0.28 \mathrm{~cm} \mathrm{H}_{2} \mathrm{O} \cdot \mathrm{s}^{2} / \mathrm{L}$ and 0.5 $\mathrm{mL} / \mathrm{cm} \mathrm{H}_{2} \mathrm{O}$, respectively, both of which were within the ranges of values reported by Dorkin et al. (15) for neonates ventilated for moderately severe respiratory disease. Similarly, the total linear resistance was assigned a nominal value of 28.5 $\mathrm{cm} \mathrm{H}_{2} \mathrm{O} \cdot \mathrm{s} / \mathrm{L}$, also within the range reported by Dorkin et al. (15). This was primarily apportioned to the peripheral airways $\left(\mathrm{R}_{\mathrm{p}}=27.5 \mathrm{~cm} \mathrm{H} \mathrm{H}_{2} \mathrm{O} \cdot \mathrm{s} / \mathrm{L}\right)$, with minimal resistance attributed to the short tracheal section between the tip of the TT and the carinal junction $\left(\mathrm{R}_{\mathrm{c}}=1 \mathrm{~cm} \mathrm{H} \mathrm{H}_{2} \mathrm{O} \cdot \mathrm{s} / \mathrm{L}\right)$.

Using the $\mathrm{P}_{\mathrm{ao}}$ waveform and the nominal mechanical characteristics of the model, we computed the oscillatory flow waveform $\left(\mathrm{V}^{\prime}\right)$ and the oscillatory pressure waveform gener-

Table 1. Nominal values and ranges of parameters in the homogeneous lung

\begin{tabular}{lcc}
\hline \multicolumn{1}{c}{ Parameter } & Nominal value & Range \\
\hline TT ID $(\mathrm{mm})$ & 2.5 & $2.5-4$ \\
TT length $(\mathrm{cm})$ & 10.5 & $8.5-14.5$ \\
$\mathrm{I}\left(\mathrm{cm} \mathrm{H} \mathrm{H}_{2} \mathrm{O} / \mathrm{L}\right)$ & 0.28 & $0.2-0.36$ \\
$\mathrm{C}_{\mathrm{g}}\left(\mathrm{mL} / \mathrm{cm} \mathrm{H}_{2} \mathrm{O}\right)$ & 0.011 & $0.008-0.067$ \\
$\mathrm{R}_{\mathrm{c}}\left(\mathrm{cm} \mathrm{H} \mathrm{H}_{2} \mathrm{O} \cdot \mathrm{s} / \mathrm{L}\right)$ & 1 & $0.1-10$ \\
$\mathrm{R}_{\mathrm{p}}\left(\mathrm{cm} \mathrm{H} \mathrm{H}_{2} \mathrm{O} \cdot \mathrm{L}\right)$ & 55 & $10-100$ \\
$\mathrm{C}\left(\mathrm{mL} / \mathrm{cm} \mathrm{H}_{2} \mathrm{O}\right)$ & 0.4 & $0.2-2.0$ \\
\hline
\end{tabular}


ated at both the junction of the parallel compartments $\left(\mathrm{P}_{\mathrm{tr}}\right)$, and within each of the alveolar compartments $\left(\mathrm{P}_{\mathrm{A1}}\right.$ and $\left.\mathrm{P}_{\mathrm{A} 2}\right)$. The flow waveform was numerically integrated to obtain $\mathrm{V}_{\mathrm{T}}$, and the pressure waveforms were separately analyzed to obtain values for the amplitude $\left(\Delta \mathrm{P}_{\text {tr }}\right.$ and $\left.\Delta \mathrm{P}_{\mathrm{A}}\right)$.

The output parameter values obtained under baseline conditions were initially compared with those obtained using the same shape and amplitude $\mathrm{P}_{\text {ao }}$ waveform, the sampling characteristics of which were altered to reflect a ventilator frequency of $1 \mathrm{~Hz}$.

Additional simulations were undertaken to systematically examine the effect on both $\mathrm{V}_{\mathrm{T}}$ and $\Delta \mathrm{P}_{\text {tr }}$ and $\Delta \mathrm{P}_{\mathrm{A}}$ by independently varying each of the mechanical parameters of the computer model across a range of clinically relevant values for $I, C_{g}, R_{c}, C$, and $R_{p}$ (Table 1) while maintaining other parameters at baseline values. The total alveolar compartment compliance $(\mathrm{C})$ and peripheral airways resistance $\left(R_{p}\right)$ were calculated such that:

$$
\begin{gathered}
\mathrm{C}=\mathrm{C}_{1}+\mathrm{C}_{2} \\
\mathrm{R}_{\mathrm{p}}=\mathrm{R}_{1} \mathrm{R}_{2} /\left(\mathrm{R}_{1}+\mathrm{R}_{2}\right) .
\end{gathered}
$$

The effects of changes in the nonlinear resistance associated with TT of varying length and ID were also simulated by altering both $\mathrm{k}_{1}$ and $\mathrm{k}_{2}$ during inspiration and expiration to include the ranges of values published by Sly et al. (14) for TT of four different ID $(2.5-4.0 \mathrm{~mm})$ and five different lengths $(8.5,9.5,10.5,12.5$, and $14.5 \mathrm{~cm}$ ). Simulations were initially performed in the homogeneous state $\left(\mathrm{C}_{1}=\mathrm{C}_{2}\right.$ and $\left.\mathrm{R}_{1}=\mathrm{R}_{2}\right)$. Computations were also performed for different ratios of $\mathrm{C}_{1}: \mathrm{C}_{2}$ and $\mathrm{R}_{1}: \mathrm{R}_{2}$ to reflect varying degrees of heterogeneous lung disease (Table 2). The values for $\mathrm{C}$ and $\mathrm{R}_{\mathrm{p}}$ were maintaine d at the nominal state $(0.4$ $\mathrm{mL} / \mathrm{cm} \mathrm{H}_{2} \mathrm{O}$ and $27.5 \mathrm{~cm} \mathrm{H} \mathrm{H}_{2} \mathrm{O} \cdot \mathrm{s} / \mathrm{L}$, respectively) for each different combination of $\mathrm{C}_{1}$ and $\mathrm{C}_{2}$, or $\mathrm{R}_{1}$ and $\mathrm{R}_{2}$. Values for $\mathrm{V}_{\mathrm{T}}$ and the amplitudes of the pressure waveforms in the distal trachea and each alveolar compartment were compared with those obtained in the nominal homogeneous condition.

In each case, the model was run for $1 \mathrm{~s}$ to reach a steady state, after which 1-s sections of data were isolated for analysis.

Table 2. Parameters for heterogeneous parallel compartment

\begin{tabular}{|c|c|c|c|c|}
\hline $\mathrm{t}_{1} / \mathrm{t}_{2}$ & $\begin{array}{c}\mathrm{C}_{1} \\
\left(\mathrm{~mL} / \mathrm{cm} \mathrm{H} \mathrm{H}_{2} \mathrm{O}\right) \\
\end{array}$ & $\begin{array}{c}\mathrm{C}_{2} \\
\left(\mathrm{~mL} / \mathrm{cm} \mathrm{H} \mathrm{H}_{2} \mathrm{O}\right)\end{array}$ & $\begin{array}{c}\mathrm{R}_{1} \\
\left(\mathrm{~cm} \mathrm{H} \mathrm{H}_{2} \mathrm{O} \cdot \mathrm{s} / \mathrm{L}\right)\end{array}$ & $\begin{array}{c}\mathrm{R}_{2} \\
\left(\mathrm{~cm} \mathrm{H} \mathrm{H}_{2} \mathrm{O} \cdot \mathrm{s} / \mathrm{L}\right)\end{array}$ \\
\hline 1.00 & 0.260 & 0.140 & 42.5 & 78 \\
\hline 1.53 & 0.222 & 0.178 & 61.1 & 50 \\
\hline 2.62 & 0.250 & 0.150 & 70.7 & 45 \\
\hline 2.75 & 0.222 & 0.178 & 88 & 40 \\
\hline 3.06 & 0.2857 & 0.114 & 61 & 50 \\
\hline 3.67 & 0.2500 & 0.150 & 88 & 40 \\
\hline 3.93 & 0.2857 & 0.114 & 70 & 45 \\
\hline 4.40 & 0.2667 & 0.133 & 88 & 40 \\
\hline 5.50 & 0.2857 & 0.1143 & 88 & 40 \\
\hline 6.87 & 0.2857 & 0.1143 & 103.1 & 37.5 \\
\hline 7.33 & 0.3077 & 0.092 & 88 & 40 \\
\hline 9.16 & 0.2857 & 0.114 & 128.3 & 35 \\
\hline 11.00 & 0.3333 & 0.067 & 88 & 40 \\
\hline 12.22 & 0.3077 & 0.092 & 128.3 & 35.0 \\
\hline 13.75 & 0.2857 & 0.114 & 178.8 & 32.5 \\
\hline 27.51 & 0.3333 & 0.067 & 178.8 & 32.5 \\
\hline
\end{tabular}
simulations
All data analyses were performed using ANADAT data analysis software (RHT-InfoDat Inc.).

Ovine model of surfactant deficient, immature lung. Cesarean section was performed on 11 date-mated Merino ewes at $126.9 \mathrm{~d} \pm 2.8 \mathrm{~d}($ mean $\pm \mathrm{SD})$ gestation $($ term $=150 \mathrm{~d})$. Lambs were sedated and delivered after tracheostomy as described previously (16). Each lamb was weighed $(2.79 \mathrm{~kg} \pm 0.47 \mathrm{~kg})$ and immediately commenced on HFOV (SensorMedics $3100 \mathrm{~A}$ ) with initial settings of $1.0 \mathrm{Fio}_{2}, 45 \mathrm{~cm} \mathrm{H}_{2} \mathrm{O}$ amplitude, $20 \mathrm{~cm} \mathrm{H}_{2} \mathrm{O}$ MAwP, $15 \mathrm{~Hz}$, and $33 \%$ inspiratory time. Ventilator amplitude settings were adjusted according to arterial blood gases obtained from an umbilical arterial catheter to achieve $\mathrm{PCO}_{2}$ in the range of $50-60 \mathrm{~mm} \mathrm{Hg}$ while MAwP was adjusted as required to achieve a $\mathrm{PO}_{2}>400 \mathrm{~mm} \mathrm{Hg}$. After initial stabilization, a thoracotomy was performed to permit measurement of alveolar pressure $\left(\mathrm{P}_{\mathrm{A}}\right)$ from the lingular lobe using the alveolar capsule technique (17). Thereafter, the lung was visually inspected to ensure optimal lung inflation was maintained with appropriate further adjustments made to the MAwP as required.

Ultraminiature piezoresistive transducers (model 8507C-2, Endevco, San Juan Capistrano, CA, U.S.A.) were used to measure both $\mathrm{P}_{\mathrm{A}}$ and pressure at the airway opening $\left(\mathrm{P}_{\mathrm{ao}}\right)$. Tracheal pressure was measured using a microtransducer (Codman/Johnson \& Johnson, Raynham, MA, U.S.A.) positioned 2 $\mathrm{cm}$ beyond the distal tip of the TT. Flow during HFOV was measured using a hot-wire anemometer (Florian, Acutronic Medical Systems AG, Hirzel, Switzerland) placed between the distal end of the patient circuit and the TT. Partitioned lung mechanics were evaluated in the lambs at $1 \mathrm{~h}$ of age using a modification of the low-frequency forced oscillation technique as described previously (18). $\mathrm{C}_{\mathrm{ti}}$ was calculated from the coefficients of $\mathrm{G}$ and $\mathrm{H}$ determined from the forced oscillatory impedance data (19) as follows:

$$
\mathrm{C}_{\mathrm{ti}}=\omega^{\alpha} / \mathrm{H} \omega
$$

Where $\omega=2 \pi \mathrm{f}, \alpha=\frac{2}{\pi} \arctan \left(\frac{H}{G}\right)$ and $\mathrm{f}$ is the ventilation frequency $(15 \mathrm{~Hz})$.

\section{RESULTS}

Homogeneous computer lung model. At nominal ventilator settings ( $15 \mathrm{~Hz}, 33 \%$ IT, $\left.\Delta \mathrm{P}_{\text {vent }} 40 \mathrm{~cm} \mathrm{H}_{2} \mathrm{O}\right)$ and mechanical parameters (Table 1), the $\mathrm{V}_{\mathrm{T}}$ was $3.4 \mathrm{~mL}$, and there was significant damping of the $\mathrm{P}_{\mathrm{ao}}$ waveform, with $24.2 \%$ transmission of $\Delta \mathrm{P}_{\text {ao }}$ to $\Delta \mathrm{P}_{\text {tr }}\left(\Delta \mathrm{P}_{\mathrm{tr}} / \Delta \mathrm{P}_{\mathrm{ao}}\right)$, and $14.5 \%$ transmission of $\Delta \mathrm{P}_{\mathrm{a}}$ to $\mathrm{P}_{\mathrm{A}}\left(\Delta \mathrm{P}_{\mathrm{A}} / \Delta \mathrm{P}_{\mathrm{ao}}\right)$. In contrast, the use of the same waveform at a more conventional frequency $(1 \mathrm{~Hz})$ produced a significantly larger $\mathrm{V}_{\mathrm{T}}(14.5 \mathrm{~mL})$ and a higher transmission of the $\Delta \mathrm{P}_{\mathrm{ao}}$ to both $\mathrm{P}_{\text {tr }}(64 \%)$ and $\mathrm{P}_{\mathrm{A}}(62.5 \%)$.

Increasing the resistance of the TT by altering the $\mathrm{k}_{1}$ and $\mathrm{k}_{2}$ values to simulate an increasing TT length from $8.5 \mathrm{~cm}$ to 14.5 $\mathrm{cm}$ increased resistance in the $2.5 \mathrm{~mm}$ ID TT from $110.2 \mathrm{~cm}$ $\mathrm{H}_{2} \mathrm{O} \cdot \mathrm{s} / \mathrm{L}$ to $132.6 \mathrm{~cm} \mathrm{H}_{2} \mathrm{O} \cdot \mathrm{s} / \mathrm{L}$ with consequent small reductions in both $\mathrm{V}_{\mathrm{T}}$ and both $\Delta \mathrm{P}_{\mathrm{tr}} / \Delta \mathrm{P}_{\mathrm{ao}}$ and $\Delta \mathrm{P}_{\mathrm{A}} / \Delta \mathrm{P}_{\mathrm{ao}}$. In contrast, changes to $\mathrm{k}_{1}$ and $\mathrm{k}_{2}$ representative of changes in the ID of the TT from $4.0 \mathrm{~mm}$ to $2.5 \mathrm{~mm}$ had a much greater effect on the TT 
resistance $\left(29.3 \mathrm{~cm} \mathrm{H} \mathrm{H}_{2} \mathrm{O} \cdot \mathrm{s} / \mathrm{L}\right.$ to $\left.118.4 \mathrm{~cm} \mathrm{H}_{2} \mathrm{O} \cdot \mathrm{s} / \mathrm{L}\right)$ and resulted in a moderate decrease in $\mathrm{V}_{\mathrm{T}}, \Delta \mathrm{P}_{\mathrm{tr}} / \Delta \mathrm{P}_{\mathrm{ao}}$, and $\Delta \mathrm{P}_{\mathrm{A}} / \Delta \mathrm{P}_{\mathrm{ao}}$ (Fig. $2 A$ ). Negligible changes were observed in $\mathrm{V}_{\mathrm{T}}, \Delta \mathrm{P}_{\mathrm{tr}} / \Delta \mathrm{P}_{\mathrm{ao}}$, or $\Delta \mathrm{P}_{\mathrm{A}} / \Delta \mathrm{P}_{\mathrm{ao}}$ after an increase in the compliance of the central compartment (Fig. 2B), inertance (Fig. 2C), or central linear resistance $\left(\mathrm{R}_{\mathrm{c}}\right)$ (Fig. $\left.2 D\right)$. Increasing the total resistance of the peripheral airways from 10 to $100 \mathrm{~cm} \mathrm{H}_{2} \mathrm{O} \cdot \mathrm{s} / \mathrm{L}$ effected a moderate linear decrease in both $\mathrm{V}_{\mathrm{T}}$ and $\Delta \mathrm{P}_{\mathrm{A}} / \Delta \mathrm{P}_{\mathrm{a}}$, whereas $\Delta \mathrm{P}_{\mathrm{tr}} / \Delta \mathrm{P}_{\text {ao }}$ increased (Fig. $2 E$ ). Decreasing alveolar compartment compliance from $2 \mathrm{~mL} / \mathrm{cm} \mathrm{H}_{2} \mathrm{O}$ to $0.25 \mathrm{~mL} / \mathrm{cm} \mathrm{H}_{2} \mathrm{O}$ had a significant effect on $\Delta \mathrm{P}_{\mathrm{A}} / \Delta \mathrm{P}_{\mathrm{ao}}$, which increased from $2.35 \%$ to $17.7 \%$, with an accompanying increase in $\Delta \mathrm{P}_{\mathrm{tr}} / \Delta \mathrm{P}_{\mathrm{ao}}$ from $10.1 \%$ to $21.2 \%$. $\mathrm{V}_{\mathrm{T}}$ was essentially unchanged over this range, apart from small reductions in $\mathrm{V}_{\mathrm{T}}$ at very low compliance (Fig. $2 F)$.

The pressure amplitude cost of ventilation in the trachea $\left(\Delta \mathrm{P}_{\mathrm{tr}} / \mathrm{f} \cdot \mathrm{V}_{\mathrm{T}}{ }^{2}\right)$ was markedly influenced by the balance between the resistance and compliance of the peripheral lung compartment (Fig. 3). In the highly compliant lung $(\mathrm{C}=2 \mathrm{~mL} / \mathrm{cm}$ $\mathrm{H}_{2} \mathrm{O}$ ), transmission of airway opening pressure to the trachea was least at a frequency of $5 \mathrm{~Hz}$, with the difference in pressure transmission between low $\left(10 \mathrm{~cm} \mathrm{H}_{2} \mathrm{O} \cdot \mathrm{s} / \mathrm{L}\right)$ and high $(75 \mathrm{~cm}$ $\mathrm{H}_{2} \mathrm{O} \cdot \mathrm{s} / \mathrm{L}$ ) resistance simulations increasing with increasing frequency. In contrast, in the poorly compliant lung $(\mathrm{C}=0.2$ $\mathrm{mL} / \mathrm{cm} \mathrm{H}_{2} \mathrm{O}$ ), a clear nadir is observed at $9 \mathrm{~Hz}$ for the high-resistance simulations, whereas the substitution of lowerresistance values shifts causes this nadir to occur at a higher frequency. The alveolar pressure cost of ventilation was most influenced by frequency in the simulations performed using the lowest compliance $\left(\mathrm{C}=0.2 \mathrm{~mL} / \mathrm{cm} \mathrm{H}_{2} \mathrm{O}\right)$. Unlike the pressure cost of ventilation in the trachea, however, the frequency at which the alveolar pressure cost of ventilation was lowest was not markedly affected by the level of $R_{p}$, within the ranges used for these simulations.

Heterogeneous lung model. $\mathrm{V}_{\mathrm{T}}$ decreased and there was an exponential decrease in the magnitude of $\Delta \mathrm{P}_{\mathrm{A} 1}$ compared with $\Delta \mathrm{P}_{\mathrm{a} 2}$ as the ratio of the time constants of the two parallel compartments $\left(\tau_{1} / \tau_{2}\right)$ increased (Fig. 4). In the special case where there was heterogeneity of both compliance and resistance but no difference between the time constants of the two compartments $\left(\tau_{1} / \tau_{2}=1\right), \Delta \mathrm{P}_{\mathrm{A} 1}$ and $\Delta \mathrm{P}_{\mathrm{A} 2}$ were identical.

Pressure transmissions predicted from lamb impedance measurements. Figure 5 illustrates the relationship between the percentage transmission of the oscillatory pressure amplitude from the airway opening to the trachea and the alveolar compartment and its relationship to the mechanical properties of the lung at $15 \mathrm{~Hz}$. Transmission to the alveolar compartment increased as the tissue compliance $\left(\mathrm{C}_{\mathrm{ti}}\right)$ decreased $(p<0.001)$.

\section{DISCUSSION}

The computer simulations and in vivo study described above have demonstrated the importance of considering the mechanical properties of the lung when assessing the exposure of the airways and the tissues to potential barotrauma during HFOV. It shows that during HFOV, TT ID and lung compartment compliance are the principal respiratory system determinants of $\Delta \mathrm{P}_{\mathrm{A}}$ and $\Delta \mathrm{P}_{\text {tr }}$ (Fig. 2, $A$ and $F$ ), while $\Delta \mathrm{P}_{\text {tr }}$ may also be

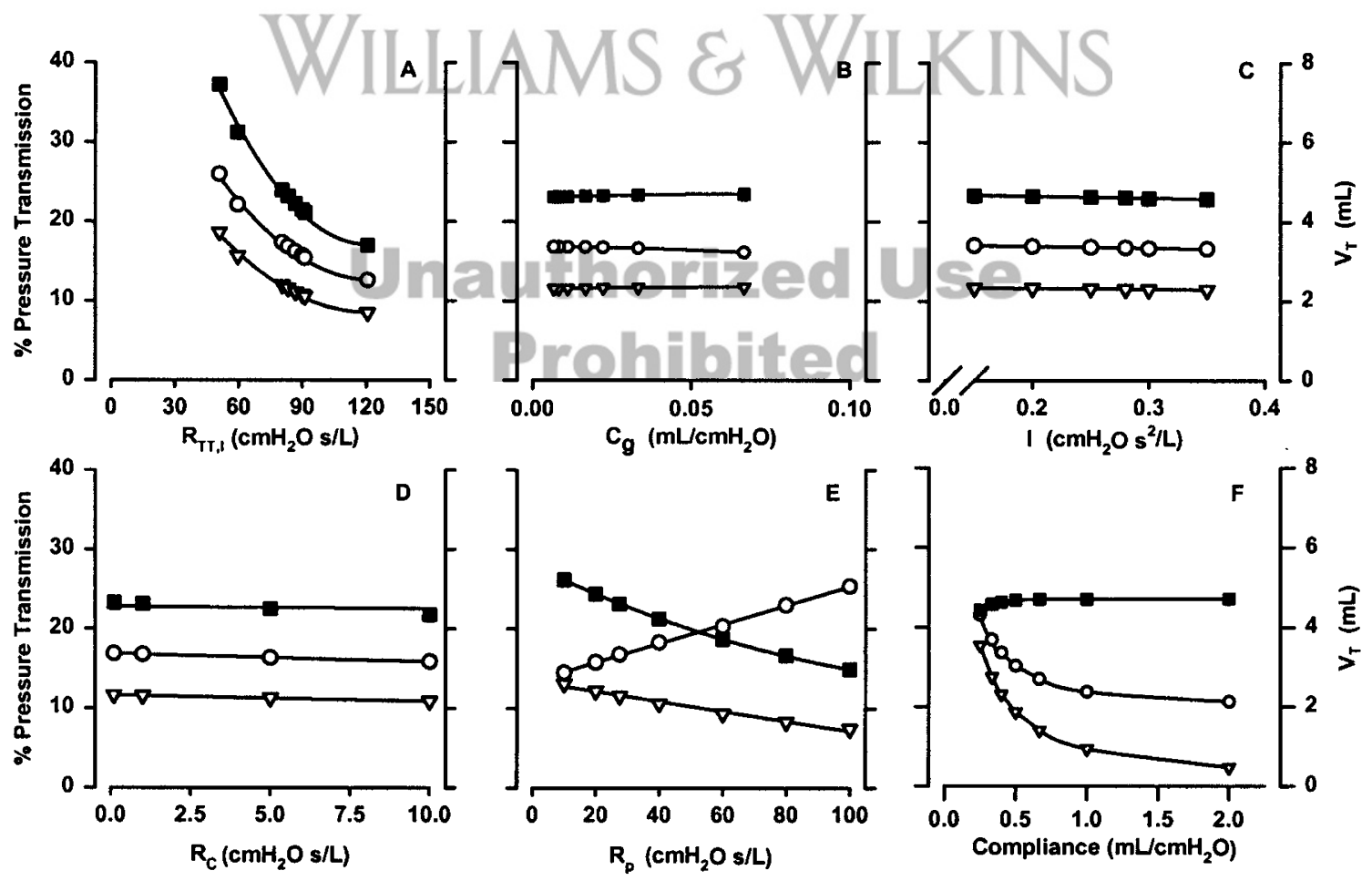

Figure 2. Pressure and volume transmission in the homogeneous computer model. The computed values of $\mathrm{V}_{\mathrm{T}}($ square $), \Delta \mathrm{P}_{\text {tr }}($ circle $)$, and $\Delta \mathrm{P}_{\mathrm{A}}($ triangle $)$ are shown for model simulations independently varying one of the following parameters: $(A)$ the inspiratory resistance through the TT $\left(\mathrm{R}_{\mathrm{TT}, \mathrm{I}}\right)$ by altering the coefficients of flow dependent resistance to reflect a 2.5 -mm ID TT of five different lengths $(8.5,9.5,10.5,12.5$, and $14.5 \mathrm{~mm})$ and a 10.5 -cm long TT with four different ID $(4.0,3.5,3.0$, and $2.5 \mathrm{~mm}) ;(B)$ central resistance $\left(\mathrm{R}_{\mathrm{c}}\right) ;(C)$ peripheral resistance $\left(\mathrm{R}_{\mathrm{p}}\right) ;(D)$ compressibility of gas in the anatomical dead space $\left(\mathrm{E}_{\mathrm{c}}\right)$; $(E)$ inertance (I); and $(F)$ alveolar compartment compliance (C). 
significantly influenced by changes in peripheral resistance (Fig. 2C). The balance between peripheral resistance and compliance may be a critical determinant of the frequency at which pressure cost to the central airways is minimized (Fig. 3). The simulation of heterogeneous lung disease showed that intrapulmonary pressure amplitudes are greater in the compartment with the smaller time constant (Fig. 4). The clinical relevance of these findings was supported by the investigations in the preterm lamb model (Fig. 5), demonstrating the increased pressure cost of ventilation to alveolar compartment associated with reduction in tissue compliance.

Computer simulations used ventilatory parameters that were chosen to reflect the settings commonly used at the commencement of HFOV in a neonate with moderately severe hyaline membrane disease. A ventilator $\mathrm{P}_{\mathrm{ao}}$ amplitude of $40 \mathrm{~cm} \mathrm{H}_{2} \mathrm{O}$ is reported as a common initial ventilator setting (20). Given the higher percentage transmission of $\Delta \mathrm{P}_{\mathrm{ao}}$ to the lung in the poorly compliant lung, the application of HFOV in this scenario may be associated with at least moderate intrapulmonary pressure amplitudes, despite minimizing $\mathrm{V}_{\mathrm{T}}$. Similarly, although a range of frequencies are used during HFOV, the choice of $15 \mathrm{~Hz}$ as the nominal frequency for simulations reflected the commonality of this setting to most of the commercially available HFO ventilators. When a lower frequency is used, the transmission of pressure to both the tracheal and alveolar compartments will be higher than shown in this study.

There have been relatively few computer models that have specifically examined the factors influencing the amplitude of the intrapulmonary pressure waveforms during $\mathrm{HFOY} \mathrm{(4,21-}$
24). Although Jackson et al. (23) observed resonant amplification within the lung periphery at particular frequencies in a model of the canine lung, their studies did not investigate how altering the mechanics may affect the magnitude of the pressure waveforms at any one frequency. The prediction of optimal gas exchange with minimal alveolar pressure fluctuations at frequencies between 1 and $4 \mathrm{~Hz}$ in the computer models used by Ghazanshahi and Khoo (22) and Khoo et al. (25) contrasts dramatically with the experimental data in normal healthy animals $(1,11)$. The most likely explanation for their predictions lies in the construction of the models, as neither considered the effect of nonlinear flow resistance through the TT during HFOV (26). More recently, van Genderingen et al. (4) have used a computer model incorporating a nonlinear TT resistance and showed marked reduction in pressure transmission to the distal end of the TT, with increasing compliance during alveolar recruitment. Similar findings have been observed by Pillow et al. (5) in an in vitro lung model. Both of these latter studies use single-compartment models that oversimplify the more common clinical scenario of intra- and interregional atelectasis and limit their analysis to either the changes in pressure at the distal tip of the TT (4), or to within the lung model itself (5). The current study thus has the advantage over previous lung models of including pressure from both the tracheal and alveolar compartment and using a parallel compartment model to examine the effect of heterogeneous lung disease. Although, unlike the models of van Genderingen et al. (4) and Venegas and Fredberg (27), the current study did not model lung volume recruitment per se, an
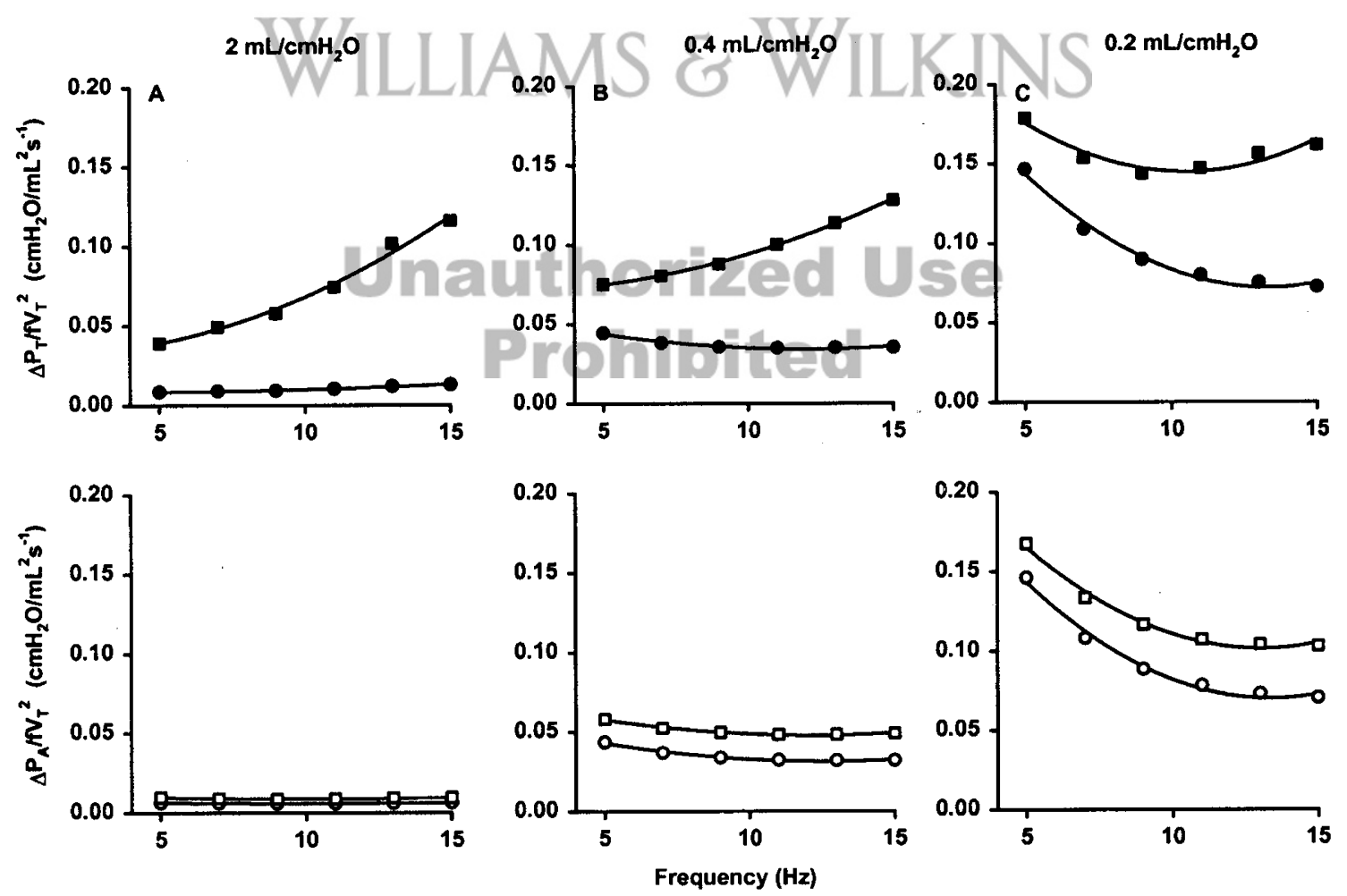

Figure 3. Pressure cost of ventilation as a function of frequency. Values are shown for the pressure cost of ventilation at the junction of parallel compartments $\left(\Delta \mathrm{P}_{\mathrm{tr}} / \mathrm{f} \cdot \mathrm{V}_{\mathrm{T}}{ }^{2}\right.$, top panel, closed symbols $)$ and within the alveolar compartment $\left(\Delta \mathrm{P}_{\mathrm{A}} / \mathrm{f} \cdot \mathrm{V}_{\mathrm{T}}{ }^{2}\right.$, lower panel, open symbols $)$. Simulations were performed at both low (circles) and high (squares) peripheral resistance $\left(\mathrm{R}_{\mathrm{p}}=10 \mathrm{~cm} \mathrm{H}_{2} \mathrm{O} \cdot \mathrm{s} / \mathrm{L}\right.$ and $75 \mathrm{~cm} \mathrm{H} \mathrm{H}_{2} \mathrm{O} \cdot \mathrm{s} / \mathrm{L}$, respectively) as well as at three different levels of alveolar compliance (left panel $=2 \mathrm{~mL} / \mathrm{cm} \mathrm{H}_{2} \mathrm{O}$, middle panel $=0.4 \mathrm{mLcm} \mathrm{H}_{2} \mathrm{O}$, and right panel $=0.2 \mathrm{~mL} / \mathrm{cm} \mathrm{H}_{2} \mathrm{O}$ ). 


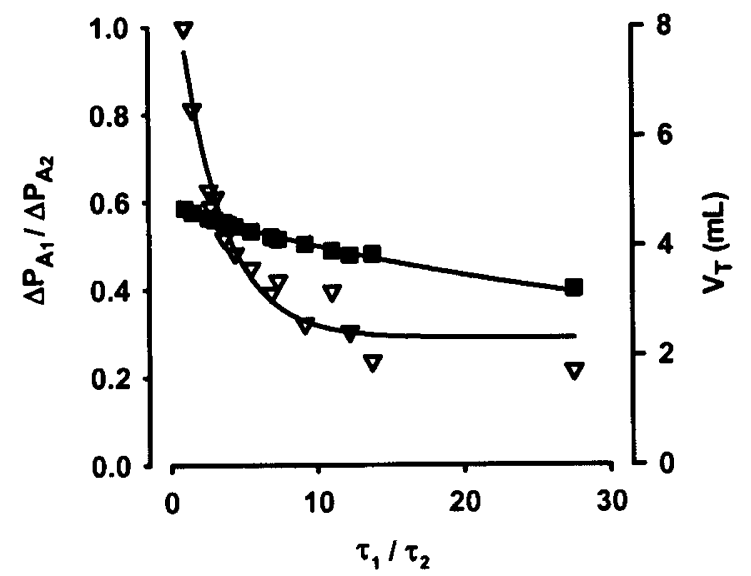

Figure 4. Effect of heterogeneous lung disease on pressure and volume. Heterogeneity was introduced by creating unequal resistance and compliance in each parallel lung compartment $\left(\mathrm{R}_{1} \neq \mathrm{R}_{2}\right)$ and $\left(\mathrm{C}_{1} \neq \mathrm{C}_{2}\right)$ while maintaining total peripheral compliance $(\mathrm{C})$ and resistance $\left(\mathrm{R}_{\mathrm{p}}\right)$ at nominal values $(0.4$ $\mathrm{mL} / \mathrm{cm} \mathrm{H}_{2} \mathrm{O}$ and $27.5 \mathrm{~cm} \mathrm{H} \mathrm{H}_{2} \mathrm{O} \mathrm{s} / \mathrm{L}$, respectively) for each combination of $\mathrm{R}_{1} \mathrm{C}_{1}$. and $\mathrm{R}_{2} \mathrm{C}_{2}$. As $\tau_{1}$ lengthened relative to $\tau_{2}, \Delta \mathrm{P}_{\mathrm{A} 1}$ decreased compared with $\Delta \mathrm{P}_{\mathrm{A} 2}$. Where heterogeneity existed but $\tau_{1}=\tau_{2}$, no difference was observed between $\Delta \mathrm{P}_{\mathrm{A} 1}$ and $\Delta \mathrm{P}_{\mathrm{A} 2}$. Triangles $=\Delta \mathrm{P}_{\mathrm{A} 1} / \Delta \mathrm{P}_{\mathrm{A} 2} ;$ squares $=\mathrm{V}_{\mathrm{T}}$.

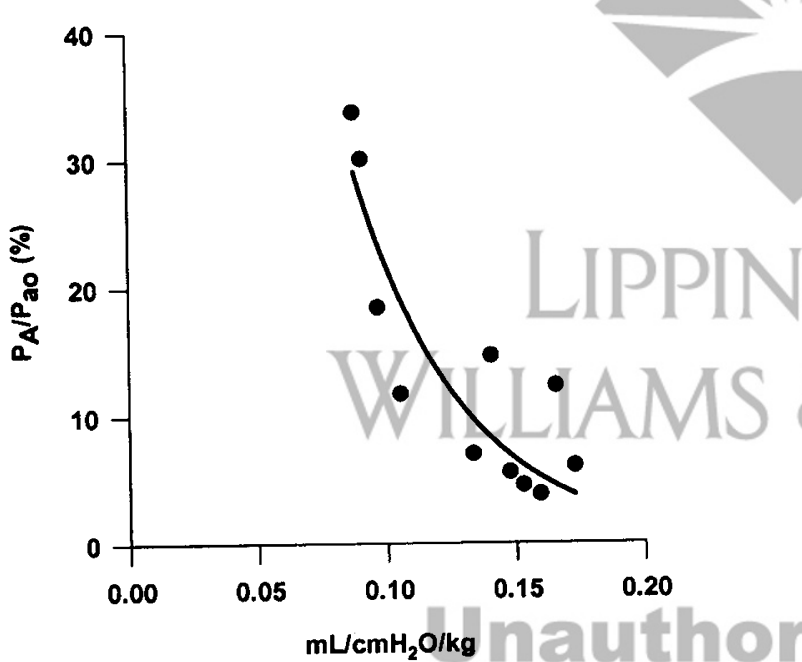

Figure 5. Effect of lung compliance on pressure transmission during HFOV in the preterm lamb. The percent transmission of the oscillatory pressure waveform from the airway opening to the alveolar compartment in relation to specific tissue compliance. Specific tissue compliance $\left(\mathrm{C}_{\mathrm{ti}, \mathrm{sp}}\right)$ was calculated from the coefficients of tissue damping and elastance at a frequency of $15 \mathrm{~Hz}$ using equation 3. Measurements were corrected for differences in birth weight.

awareness of changes in resistance and compliance as the lung size changes from under- to overdistension provides a means of applying these findings to the clinical setting.

The airway compartment beyond the tip of the TT comprised an inertance, a proximal resistance, and a central compliance. During conventional ventilation in intubated neonates, approximately $90 \%$ of the respiratory system inertance may be contained within the TT (15). At higher frequencies, however, such as those used during HFOV, inertance plays a significant role in reducing the amplitude of the oscillatory pressure waveforms as it passes from the airway opening through the TT and the proximal airways compartment. Values of I have not been published for the different TT. Although the nominal value used in this study represents an average value derived from a group of infants with an average weight of $1.9 \pm 0.3 \mathrm{~kg}$ and may underestimate the inertance of the extremely low birthweight neonate intubated with a $2.5-\mathrm{mm}$ TT, increasing the inertance to the highest value measured by Dorkin et al. (15) in their group of infants with moderately severe respiratory distress had minimal impact on the amplitudes of $\Delta \mathrm{P}_{\mathrm{tr}}$ and $\Delta \mathrm{P}_{\mathrm{A}}$.

The central compliance, $\mathrm{C}_{\mathrm{g}}$ was included in the model to account for the compliant properties of the extrapulmonary airways. The nominal value of $0.01 \mathrm{~mL} / \mathrm{cm} \mathrm{H}_{2} \mathrm{O}$ primarily represents the compressibility of gas in the anatomical dead space and presumes that using a high-volume strategy results in essentially rigid walls of the proximal airway and TT (28). Our computations showed that increasing $\mathrm{C}_{\mathrm{g}}$ to reflect the increased compliance of airway walls that may be evident at suboptimal MAwP had essentially no effect on the amplitude of the intrapulmonary pressure wave.

The resistances of the central airways and peripheral airway compartments beyond the TT were considered constant, reflecting laminar rather than turbulent flow. This may represent an oversimplification of the biologic state, as flow may be turbulent in the first few generations of the bronchial tree (29). As the diameter of the TT is likely to be smaller than most of the most proximal airways, however, the contribution of central airways to the overall nonlinear system resistance is negligible. The inclusion of a linear rather than a nonlinear resistance at this level is unlikely to have a major effect on the magnitude of intrapulmonary distending pressures $\left(\Delta \mathrm{P}_{\text {tr }}\right.$ and $\left.\Delta \mathrm{P}_{\mathrm{A}}\right)$.

Dorkin et al. (15) measured an average airways resistance of $28.5 \mathrm{~cm} / \mathrm{H}_{2} \mathrm{O} \cdot \mathrm{s} / \mathrm{L}$, obtained after subtracting the contribution of the TT. Little information is available to guide the division of this resistance into contributions of the central $\left(\mathrm{R}_{\mathrm{c}}\right)$ and peripheral $\left(\mathrm{R}_{\mathrm{p}}\right)$ airway compartments. We applied a nominal resistance to the peripheral airways of $27.5 \mathrm{~cm} \mathrm{H}_{2} \mathrm{O} \cdot \mathrm{s} / \mathrm{L}$, which was an order of magnitude higher than the central airways resistance $\left(1 \mathrm{~cm} \mathrm{H}_{2} \mathrm{O} \cdot \mathrm{s} /\right.$ L), consistent with the approach used by Bates et al. (12) in their modeling studies. Although increasing the peripheral resistance effected a reduction in both $\mathrm{V}_{\mathrm{T}}$ and the magnitude of the alveolar pressure swings, it created higher pressure swings in the more proximal airways. This suggests that the delivery of HFOV in the presence of significant small airways disease may result in barotrauma in the more proximal airway compartments, even at low $\mathrm{V}_{\mathrm{T}}$.

Venegas and Fredberg (27) have published a detailed modeling analysis of the cost of flow and pressure during highfrequency ventilation. Among other factors, they examined how both airway resistance and compliance might impact the optimal ventilation frequency for use during HFOV, observing that reduced compliance shifted the optimal frequency higher, whereas increased resistance altered the minimum pressure cost to a lower frequency. The variables they used for their simulations reflected a relatively high compliance for neonatal respiratory distress syndrome $\left(1.5 \mathrm{~mL} / \mathrm{cm} \mathrm{H}_{2} \mathrm{O}\right)$, whereas the lung resistance did not include a flow-dependent term. Although our study describes the cost-per-unit ventilation rather than per-unit flow, our results are similar and highlight the 
importance of measures of peripheral lung mechanics when determining optimal ventilation frequency.

The combination of heterogeneous lung disease and HFOV may create large differences in phasic peak-to-trough distending pressures between diseased versus more normally aerated regions. In considering both the results obtained from our model study and those observed by van Genderingen et al. (4), it is likely that the scenario of small $\Delta \mathrm{P}_{\mathrm{A}}$ in well-aerated areas compared with high $\Delta \mathrm{P}_{\mathrm{A}}$ in atelectatic regions could be reversed as the healthy lung units are overdistended in the process of recruiting poorly aerated zones.

Although Frantz and Close (1) clearly demonstrated the potential of HFOV to reduce both barotrauma and volutrauma, their studies were performed in healthy adult rabbits. Kamitsuka et al. (3) used alveolar capsules to measure alveolar pressure during HFOV in rabbits before and after saline lavage. Although the experiments were primarily designed to determine whether there are ventilator settings that optimize gas exchange during HFOV, their results suggested a difference between the cyclical distending pressure in the lung after saline lavage compared with pressures recorded in the healthy state. Our computer simulations and in vivo measurements confirm these findings and the results of our recent in vitro experiments (5), showing that the alveolar pressure amplitudes in the structurally and functionally preterm lung are likely to be substantially higher than those observed during experiments in healthy animals. In the case of severe respiratory disease, when these pressure amplitudes are superimposed on moderately high MAwP, peak pressures may approach those generated during conventional ventilation. In the homogeneously diseased lung, maneuvers that increase compliance and minimize peripheral resistance, such as exogenous surfactant administration and volume recruitment, may be paramount to minimizing the exposure of immature lung architecture to excessive pressure stress.

\section{CONCLUSIONS}

In summary, the combined computer simulations and in vivo experimental findings of this study provide strong evidence of the impact that the mechanical characteristics of the intubated respiratory system may have on the cyclical changes in pressure to which both the proximal airways and the peripheral lung are exposed. The effect of the TT on the damping of the pressure waveform has been widely acknowledged. However, clinicians need to be aware that reduced compliance may markedly increase the transmission of the driving pressure amplitude from the airway opening to the alveolar compartment. Likewise, awareness also needs to be raised with regard to the potentially increased pressure transmission to alveolar units surrounding the central airways that might occur in the presence of increased peripheral resistance. Whereas, in healthy subjects, HFOV promotes effective ventilation at low $\mathrm{V}_{\mathrm{T}}$ and low alveolar pressure amplitudes, these findings suggest that the use of HFOV to protect the preterm infant with respiratory disease from volutrauma needs to be coupled with judicious selection of ventilator parameters and strategies that optimize respiratory mechanics to simultaneously safeguard the lung from highly repetitive barotrauma.
Acknowledgments. The authors thank Professors Alan Jobe, Machiko Ikegami, and John Newnham for assistance in making the lamb studies possible.

\section{REFERENCES}

1. Frantz III ID, Close R 1985 Alveolar pressure swings during high frequency ventilation in rabbits. Pediatr Res 19:162-166

2. Allen JL, Frantz III ID, Fredberg JJ 1985 Regional alveolar pressure during periodic flow. J Pediatr 76:620-629

3. Kamitsuka MD, Boynton BR, Villanueva D, Vreeland PN, Frantz III ID 1990 Frequency, tidal volume, and mean airway pressure combinations that provide adequate gas exchange and low alveolar pressure during high frequency oscillatory ventilation in rabbits. Pediatr Res 27:64-69

4. van Genderingen HR, Versprille A, Leenhoven T, Markhorst DG, van Vught AJ, Heethaar RM 2001 Reduction of oscillatory pressure along the endotracheal tube is indicative for maximal respiratory compliance during high-frequency oscillatory ventilation. Pediatr Pulmonol 31:458-463

5. Pillow JJ, Wilkinson MH, Neil HN, Ramsden CA 2001 In vitro performance characteristics of high frequency oscillatory ventilators. Am J Respir Crit Care Med 164:1019-1024

6. deLemos RA, Coalson JJ, Gerstmann DR, Null Jr DM, Ackerman NB, Escobedo MB, Robotham JL, Kuehl TJ 1987 Ventilatory management of infant baboons with hyaline membrane disease: the use of high frequency ventilation. Pediatr Res 21:594-602

7. Gerstmann DR, Minton SD, Stoddard RA, Meredith KS, Monaco F, Bertrand JM, Battisti O, Langhendries JP, Frrancois A, Clark RH 1996 The Provo Multicenter Early High-frequency Oscillatory Ventilation Trial: improved pulmonary and clinical outcome in respiratory distress syndrome. Pediatrics 98:1044-1057

8. Ogawa Y, Miyasaka K, Kawano T, Imura S, Inukai K, Okuyama K, Oguchi K, Togari H, Nishida H, Mishina J 1993 A multicenter randomized trial of high frequency oscillatory ventilation as compared with conventional mechanical ventilation in preterm infants with respiratory failure. Early Hum Dev 32:1-10

9. The HiFO Study Group 1993 Randomized study of high-frequency oscillatory ventilation in infants with severe respiratory distress syndrome. J Pediatr 122:609-619

10. Henderson-Smart DJ, Bhuta T, Cools F, Offringa M 2000 Elective high frequency oscillatory ventilation versus conventional ventilation for acute pulmonary dysfunction in preterm infants. Cochrane Database Syst Rev CD000104

11. Allen J, Fredberg J, Keefe D, Frantz III I 1985 Alveolar pressure magnitude and asynchrony during high-frequency oscillations of excised rabbit lungs. Am Rev Respir Dis 132:343-348

12. Bates J, Sly P, Kochi T, Martin J 1987 The effect of a proximal compliance on interrupter measurements of resistance. Respir Physiol 70:301-312

13. Fredberg J, Glass G, Boynton B, Frantz III I 1987 Factors influencing mechanical performañe of neonatal high-frequency ventilators. J Appl Physiol 62:2485-2490

14. Sly PD, Brown KA, Bates JHT, Spier S, Milic-Emili J 1987 Noninvasive determination of respiratory mechanics during mechanical ventilation of neonates. Pediatr Pulmonol 4:39-47

15. Dorkin H, Stark A, Werthammer J, Strieder D, Fredberg J, Frantz III I 1983 Respiratory system impedance from 4 to $40 \mathrm{~Hz}$ in paralyzed intubated infants with respiratory disease. J Pediatr 72:903-910

16. Jobe A, Polk D, Ikegami M, Newnham J, Sly P, Kohen R, Kelly R 1993 Lung responses to ultrasound-guided fetal treatments with corticosteroids in preterm lambs. J Appl Physiol 75:2099-2105

17. Gerstmann DR, Fouke JM,Winter DC, Taylor AF, deLemos RA 1990 Proximal, tracheal and alveolar pressures during high-frequency oscillatory ventilation in a normal rabbit model. Pediatr Res 28:367-373

18. Pillow JJ, Hall GL, Willet KE, Jobe AH, Hantos Z, Sly PD 2001 Effects of gestation and antenatal steroid on airway and tissue mechanics in newborn lambs. Am J Respir Crit Care Med 163:1158-1163

19. Hantos Z, Daróczy B, Suki B, Nagy S, Fredberg J 1992 Input impedance and peripheral inhomogeneity of dog lungs. J Appl Physiol 72:168-172

20. Mammel M, Boros S 1996 High-frequency ventilation. In: Goldsmith J, Karotkin E (eds) Assisted Ventilation of the Neonate, 3rd Ed. WB Saunders, Philadelphia, pp 199-214

21. Ghazanshahi S, Marmarelis V, Yamashiro S 1986 Analysis of the gas exchange system dynamics during high-frequency ventilation. Ann Biomed Eng 14:525-542

22. Ghazanshahi S, Khoo M 1993 Optimal application of high-frequency ventilation in infants: a theoretical study. IEEE Trans Biomed Eng 40:788-796

23. Jackson A, Tabrizi M, Kotlikoff M, Voss J 1984 Airway pressures in an asymmetrically branched airway model of the dog respiratory system. J Appl Physiol 57:1223-1230

24. Khoo M, Yamashiro S, Yamashiro P 1989 Minimization of lung pressure swings during high-frequency ventilation: a model. J Appl Physiol 67:993-1000

25. Khoo M, Slutsky A, Drazen J, Solway J, Gavriely N, Kamm R 1984 Gas mixing during high-frequency ventilation: an improved model. J Appl Physiol 57:493-506

26. Gavriely N, Solway J, Loring S, Butler J, Slutsky A, Drazen J 1985 Pressure-flow relationships of endotracheal tubes during high-frequency ventilation. J Appl Physiol 59:3-11

27. Venegas JG, Fredberg JJ 1994 Understanding the pressure cost of ventilation: why does high-frequency ventilation work? Crit Care Med 22:S49-S57

28. Lai Fook S, Hyatt R, Rodarte J 1978 Effect of parenchymal shear modulus and lung volume on bronchial pressure-diameter behaviour. J Appl Physiol 44:859-868

29. Slutsky A 1984 Mechanisms affecting gas transport during high-frequency oscillation. Crit Care Med 12:713-717 